\title{
Rediscovery and geographic distribution of Philodryas agassizii (Jan, 1863) (Squamata: Dipsadidae) in the state of Paraná, Southern Brazil
}

\author{
Gilberto Alves de Souza Filho * \\ Luciano Leandro Plombon \\ Hori Consultoria Ambiental \\ Rua Coronel Temístocles de Souza Brasil, 311, CEP 82.520-210, Curitiba $\square$ PR, Brazil \\ * Corresponding author \\ gilbertoasfilho@yahoo.com.br
}

Submetido em 10/06/2013

Aceito para publicação em 16/12/2013

\section{Resumo}

Redescoberta e distribuição geográfica de Philodryas agassizii (Jan, 1863) (Squamata: Dipsadidae) no estado do Paraná, Sul do Brasil. Philodryas agassizii (Dipsadidae) ocorre no Brasil, Argentina e Uruguai; no Brasil, conta com registros em áreas abertas das regiões Nordeste, Centro-Oeste, Sudeste e Sul. No estado do Paraná, ela apresenta registros antigos no sudeste do estado. Relatamos, aqui, a redescoberta de P. agassizii no Paraná, quarenta anos após o último registro, e revisamos sua distribuição no estado, incluindo a região centro-sul.

Palavras-chave: Estepe; Mata Atlântica; Philodryadini; Serpentes

\section{Abstract}

Philodryas agassizii (Dipsadidae) occurs in Brazil, Argentina, and Uruguay; in Brazil, it has been recorded in open areas of the regions Northeast, Central-West, Southeast and South. In the state of Paraná, it has only old records in southeastern of the state. We report, here, the rediscovery of P. agassizii in Paraná, forty years after the last record, and review its distribution within the state, including the central-south region.

Key words: Atlantic Forest; Philodryadini; Snakes; Steppe

Philodryas Wagler, 1830 is a Neotropical snake genus currently consisting of twenty species distributed throughout South America (PETERS; OREJASMIRANDA, 1986; ZAHER et al., 2008; UETZ; HOSEK, 2013). Philodryas agassizii (Jan, 1863) had been formerly allocated to the genus Pseudablabes by Boulenger (1896), but it has been moved to Philodryas by Zaher et al. (2009). The species is distinguished from other Philodryadini due to a combination of 13 dorsal midbody scale rows, small body size, and diet specialized in arthropods (PETERS; OREJAS-MIRANDA, 1986; MARQUES et al., 2006). It occurs in Brazil, Argentina, and Uruguay (PETERS; OREJAS-MIRANDA, 1986; GIRAUDO; SCROCCHI, 2002; ACHAVAL; OLMOS, 2003; MARQUES et al., 2006). In Brazil, $P$. agassizii may be found in open areas in the states of 
Goiás, Mato Grosso, Mato Grosso do Sul, Minas Gerais, São Paulo, Paraná, Santa Catarina, and Rio Grande do Sul, as well as in Distrito Federal (MARQUES et al., 2006; GHIZONI JR. et al., 2009). Recently, it has also been recorded in northeastern Brazil, in the state of Bahia (HAMDAN; LIRA-DA-SILVA, 2012).

In the state of Paraná, Philodryas agassizii has two records in the literature: one for the municipality of Palmeira and another for "Nova Restinga" (a locality in the municipality of Porto Amazonas) (MARQUES et al., 2006). We consulted the most representative Brazilian herpetological collections with reptiles from the state of Paraná: Departamento de Zoologia da Universidade Federal do Rio Grande do Sul (UFRGS), Instituto Butantan (IBSP), Museu de Ciências e Tecnologia da Pontifícia Universidade Católica do Rio Grande do Sul (MCP), Museu de Ciências Naturais da Fundação Zoobotânica do Rio Grande do Sul (MCN), Museu de História Natural Capão da Imbuia (MHNCI), Museu de Zoologia da Universidade de São Paulo (MZUSP), Museu Nacional da Universidade Federal do Rio de
Janeiro (MNRJ), Setor de Zoologia da Universidade Federal de Santa Maria (ZUFSM), Universidade de Passo Fundo (CRUPF); and a further record of the species was added to the neighboring municipality of Ponta Grossa (Appendix 1). These three localities are located in southeastern Paraná, within the Atlantic Forest biome, and they are characterized by Steppe phytophysiognomy (RODERJAN et al., 2002). All previous records of $P$. agassizii from Paraná are old, the last one dating from 1971 (voucher IBSP 32632).

During field-work in the municipality of Pinhão, one individual of Philodryas agassizii $(\mathrm{SVL}=230 \mathrm{~mm}$; tail length $=90 \mathrm{~mm} ; 8.0 \mathrm{~g}$; male; Figure 1) was found on November 8 2011, in the morning, crossing a road between wheat plantations $\left(25^{\circ} 40 \square 50 \measuredangle \mathrm{S}, 51^{\circ} 57[32 \square \mathrm{W}\right.$; $865 \mathrm{~m}$ a.s.1.). The individual was collected (permit IBAMA number 073/2010) and deposited in the herpetological collection of the Museu de História Natural Capão da Imbuia at Curitiba, Paraná (MHNCI 14273). Identification was based on Peters and OrejasMiranda (1986).

FIGURE 1: Philodryas agassizii found in the municipality of Pinhão, Paraná, Southern Brazil (MHNCI 14273).

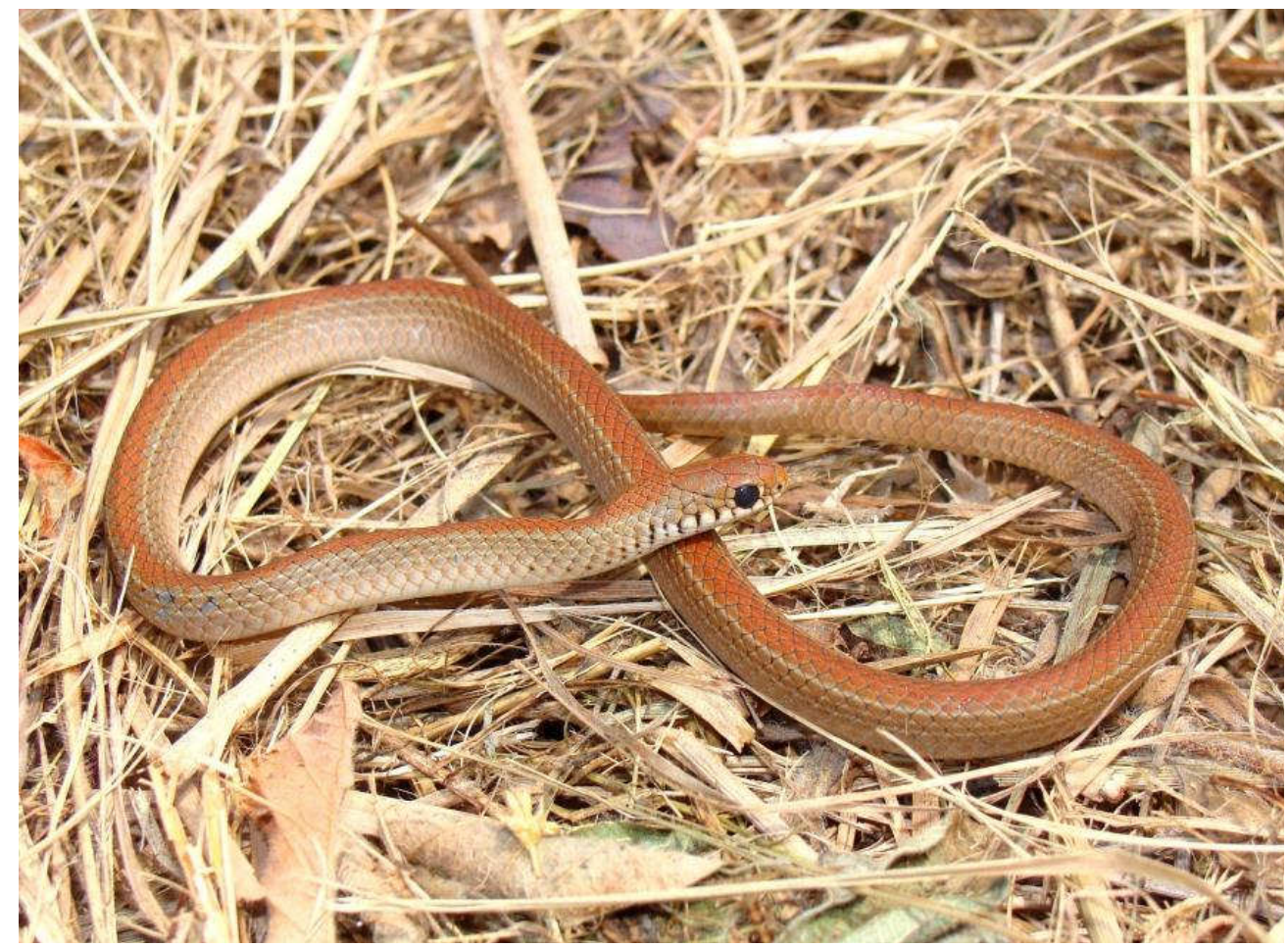


This record represents the rediscovery of Philodryas agassizii in Paraná 40 years after the last record and it expands the occurrence of this species for the central-south region of the state, about $200 \mathrm{~km}$ westward from the closest previously known site (Figure 2). The municipality of Pinhão is within the Atlantic Forest biome, and it is characterized by Steppe phytophysiognomy, corroborating the distribution pattern previously observed for the species in the state of Paraná.

Marques et al. (2006) and Winck et al. (2007) indicate that Philodryas agassizii is very demanding with regard to habitat quality; however, the site of this record and the surrounding areas of Pinhão are very disturbed, dominated by large plantations. This apparent contradiction suggests that this species uses plantations on a transient basis to move between patches of suitable habitats and that $P$. agassizii must have some resilience to poor habitat quality.

\section{Acknowledgments}

The authors thank to Lucas R. Mariotto and Fernando J. Venâncio, for their assistance during fieldwork; to Instituto de Tecnologia para o Desenvolvimento (LACTEC) and Centrais Elétricas do Rio Jordão S/A (ELEJOR), for logistic support in Pinhão; to C. C. Mello (MZUSP), F. L. Franco and V. J. Germano (IBSP), G. M. F. Pontes (MCP), J. C. de Moura-Leite (MHNCI), L. Verrastro (UFRGS), M. L. de Araújo and M. L. M. Alves (MCN), N. Zanella (CRUPF), P. G. H. Passos and P. H. M. S. Pinna (MNRJ), and S. T. Z. Cechin and C. Pietczak (ZUFSM), for information on P. agassizii specimens from Paraná; to Davi L. Pantoja, for relevant suggestions on the manuscript. We also thank to two anonymous referees, for their reviews and comments on the text.

FIGURE 2: Records of Philodryas agassizii in the state of Paraná, Southern Brazil.

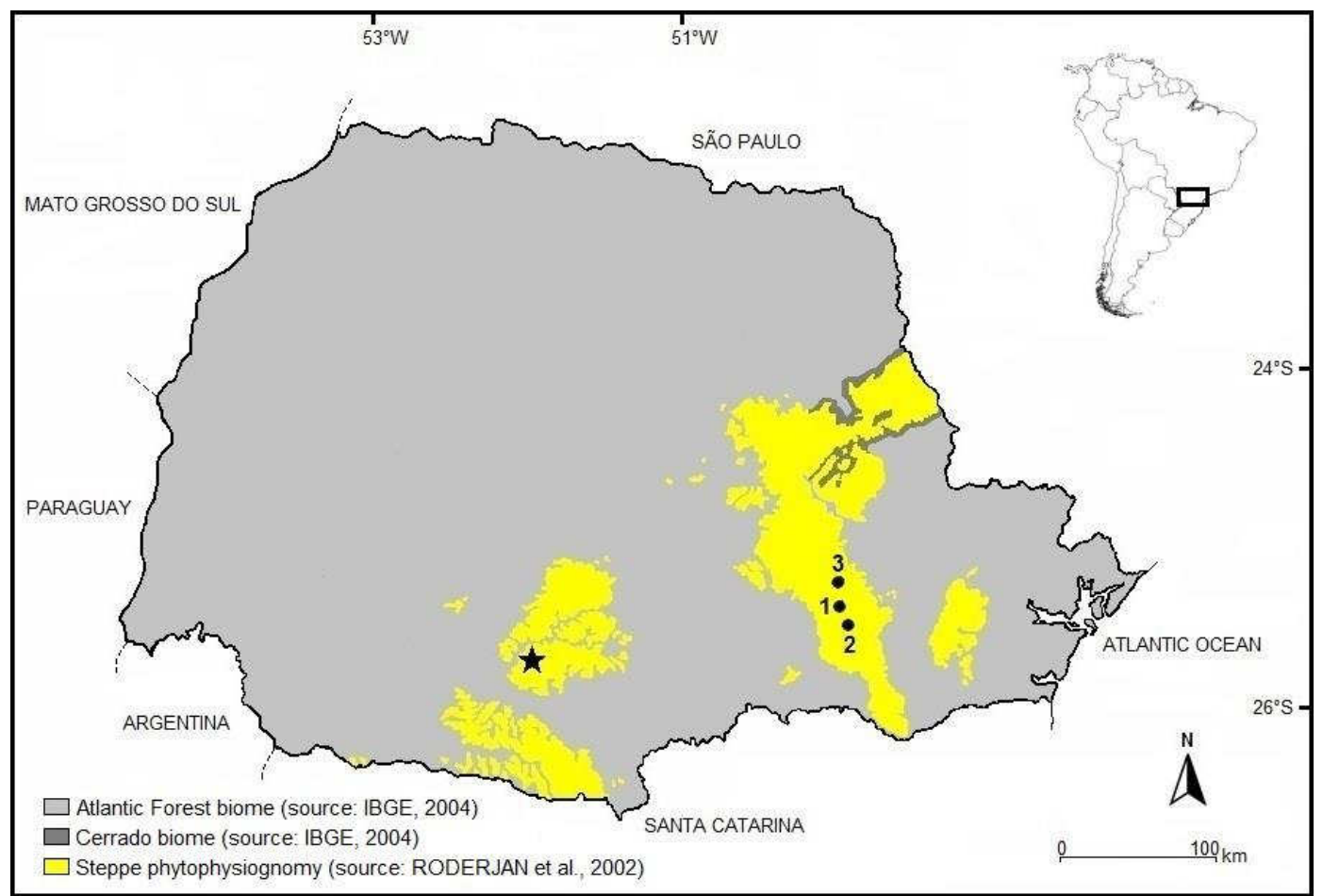

Numbers refer to previous records (literature and museum): 1. Palmeira; 2. Nova Restinga, Porto Amazonas; 3. Ponta Grossa. The star indicates the new occurrence, in the municipality of Pinhão, central-south region of Paraná. 


\section{References}

ACHAVAL, F.; A. OLMOS. Anfibios y reptiles del Uruguay. 2. ed. Montevideo: Graphis Impresora, 2003. 136 p.

BOULENGER, G. A. Catalogue of the snakes in the British Museum (Natural History). Vol. III. London: Trustees of the British Museum (Natural History), 1896. 727 p.

GHIZONI JR., I. R.; KUNZ, T. S.; CHEREM, J. J.; BÉRNILS, R. $\mathrm{S}$. Registros notáveis de répteis de áreas abertas naturais do planalto e litoral do Estado de Santa Catarina, sul do Brasil. Biotemas, Florianópolis, v. 22, n. 3, p. 129-141, 2009.

GIRAUDO, A. R.; SCROCCHI, G. J. Argentinean snakes. An annotated checklist. Smithsonian Herpetological Information Service, Washington, v. 132, p. 1-53, 2002.

HAMDAN, B.; LIRA-DA-SILVA, R. M. The snakes of Bahia State, northeastern Brazil: species richness, composition and biogeographical notes. Salamandra, Rheinbach, v. 48, n. 1, p. 31$50,2012$.

IBGE $\square$ INSTITUTO BRASILEIRO DE GEOGRAFIA E ESTATÍSTICA. Mapa de Biomas do Brasil. 2004. Accessible at: $<$ http: www.ibge. gov.br>. Captured on: 25 November 2013.

MARQUES, O. A. V.; SAWAYA, R. J.; STENDER-OLIVEIRA, F.; FRANÇA, F. G. R. Ecology of the colubrid snake Pseudablabes agassizii in south-eastern South America. Herpetological Journal, Montrose, v. 16, p. 37-45, 2006.

PETERS, J. A.; OREJAS-MIRANDA, B. Catalogue of the Neotropical Squamata. Part I. Snakes. Revisited edition (originally published in 1970), Addenda and corrigenda by P.E. Vanzolini. Washington: United States National Museum Bulletin, 1986. 347 p.
RODERJAN, C. V.; GALVÃO, F.; KUNIYOSHI, Y. S.; HATSCHBACH, G. G. As Unidades fitogeográficas do estado do Paraná, Brasil. Ciência \& Ambiente, Santa Maria, v. 24, p. 75-92, 2002.

UETZ, P.; HOSEK, J. The reptile database. 2013. Accessible at: $<$ http: www.reptile database.org>. Captured on: 5 October 2013.

WINCK, G. R.; SANTOS, T. G.; CECHIN, S. Z. Snake assemblage in a disturbed grassland environment in Rio Grande do Sul State, southern Brazil: population fluctuations of Liophis poecilogyrus and Pseudablabes agassizii. Annales Zoologici Fennici, Helsinki, v. 44, p. 321-332, 2007.

ZAHER, H.; GRAZZIOTIN, F. G.; CADLE, J. E.; MURPHY, R. W.; MOURA-LEITE, J. C. DE; BONATTO, S. L. Molecular phylogeny of advanced snakes (Serpentes, Caenophidia) with an emphasis on South American Xenodontines: a revised classification and descriptions of new taxa. Papéis Avulsos de Zoologia, São Paulo, v. 49, n. 11, p. 115-153, 2009.

ZAHER, H.; SCROCCHI, G.; MASIERO, R. Rediscovery and redescription of the type of Philodryas laticeps Werner, 1900 and the taxonomic status of P. oligolepis Gomes, 1921 (Serpentes, Colubridae). Zootaxa, Auckland, v. 1940, p. 25-40, 2008.

\section{Appendix 1}

All known records and available vouchers of Philodryas agassizii from Paraná, Southern Brazil.

Nova Restinga, municipality of Porto Amazonas: IBSP 20896. Palmeira: IBSP 10247, 10479, 10480, 15947, 15995. Pinhão: MHNCI 14273. Ponta Grossa: IBSP 32632; MCN 3349. 